\title{
Spatial and temporal diet variability of Adélie (Pygoscelis adeliae) and Emperor (Aptenodytes forsteri) Penguin: a multi tissue stable isotope analysis
}

\author{
Vahideh Jafari ${ }^{1}$ - Deborah Maccapan ${ }^{1} \cdot$ Giulio Careddu ${ }^{1} \cdot$ Simona Sporta Caputi ${ }^{1}$ Edoardo Calizza ${ }^{1}$ - Loreto Rossi $^{1}$. \\ Maria Letizia Costantini ${ }^{1}$
}

Received: 8 February 2020 / Revised: 8 March 2021 / Accepted: 30 July 2021 / Published online: 10 August 2021

(c) The Author(s) 2021

\begin{abstract}
The Ross Sea, Antarctica, supports large populations of Emperor Penguin (Aptenodytes forsteri) and Adélie Penguin (Pygoscelis adeliae), two key meso-predators that occupy high trophic levels. Despite these species are largely studied, little is known about their diet outside the breeding period. In the present study, we investigated the intra-annual diet of Adélie and Emperor Penguins belonging to five colonies in the Ross Sea through the stable isotope analysis of different tissues (feathers and shell membranes), synthetized in different seasons, and guano that indicates recent diet. Penguin samples and prey (krill and fish) were collected during the Antarctic spring-summer. $\delta^{13} \mathrm{C}$ and $\delta^{15} \mathrm{~N}$ of tissues and guano indicate spatio-temporal variation in the penguin diet. The krill consumption by Adélie Penguins was lowest in winter except in the northernmost colony, where it was always very high. It peaked in spring and remained prevalent in summer. The greatest krill contribution to Emperor Penguin's diet occurred in summer. The relative krill and fish consumption by both species changed in relation to the prey availability, which is influenced by seasonal sea ice dynamics, and according to the penguin life cycle phases. The results highlight a strong trophic plasticity in the Adélie Penguin, whose dietary variability has been already recognized, and in the Emperor Penguin, which had not previously reported. Our findings can help understand how these species might react to resource variation due to climate change or anthropogenic overexploitation. Furthermore, data provides useful basis for future comparisons in the Ross Sea MPA and for planning conservation actions.
\end{abstract}

Keywords Penguin ecology $\cdot$ Ross Sea $\cdot$ Sea ice $\cdot$ Krill $\cdot$ Fish

\section{Introduction}

The Ross Sea is one of the most biologically productive regions of the Antarctic continent (Arrigo et al. 2002). It is characterized by high biodiversity (Laffoley et al. 2019) and since October 2016 it is the largest marine protected area in the world (Brooks et al., 2020). The area supports large populations of species occupying high trophic levels, including the two key meso-predators, Emperor Penguin (Aptenodytes forsteri) and Adélie Penguin (Pygoscelis adeliae). Emperor Penguin lives and reproduces on the pack ice. It has a diet based mainly on fish and, to a lesser extent, on crustaceans

Edoardo Calizza

edoardo.calizza@uniroma1.it

1 Department of Environmental Biology, Sapienza University of Rome, Via dei Sardi 70, 00185 Rome, Italy and cephalopods (Kirkwood and Robertson 1997; Cherel and Kooyman 1998; Burns and Kooyman 2001; Cherel 2008). The diet of the smaller Adélie Penguin, a species that spends part of its life cycle on sea ice but reproduces on land, is mainly based on crustaceans belonging to the genus Euphausia, primarily Antarctic krill (Euphausia superba) and ice krill (Euphausia crystallorophias) and, to a lesser extent, on fish (Ainley 2002; Ainley et al. 2003). The Antarctic silverfish (Pleuragramma antarctica) represents the main fish prey of both penguin species (Wienecke and Robertson 1997; Cherel 2008; Tierney et al. 2008). The availability of krill and $P$. antarctica as prey for penguins is related to sea ice dynamics (Ainley et al. 1998). In fact, increased availability of krill as prey for penguins seem to occur in seasons or areas characterized by a greater pack ice presence while there is an increase in fish availability in areas without sea ice (Ainley et al.1998, 2003; Ainley 2002; Strickland et al., 2008; Olmastroni et al. 2020). 
Although these penguin species are extensively studied due to their considerable ecological and conservation importance, studies related to their trophic ecology are limited to specific periods of the year, such as the chick-rearing period that corresponds to summer for Adélie Penguin and spring for Emperor Penguin (Tierney et al. 2008; Juáres et al. 2016). As a result, for the Adélie Penguin there is a paucity of diet information in spring, and for the Emperor Penguin little is known about its trophic ecology in summer (Cherel 2008). Very few data are available on the winter diet of both species (Wienecke and Robertson 1997; Burns and Kooyman 2001).

The scarcity of data about these predators in specific periods of the year is constrained by their life cycle (Juáres et al. 2016). Indeed, these species perform long migrations in different phases of their life cycle, making it difficult to obtain continuous observations and sample collections (Juáres et al. 2016). Such migrations, coupled with the extreme conditions of the Antarctic environment, in particular during winter, make the reconstruction of the penguins' diet difficult outside their breeding areas (Cherel 2008; Tierney et al. 2008; Juáres et al. 2016). Stable isotope analysis (SIA) of Carbon $\left({ }^{13} \mathrm{C} /{ }^{12} \mathrm{C}\right)$ and Nitrogen $\left({ }^{15} \mathrm{~N} /{ }^{14} \mathrm{~N}\right)$ has been increasingly and successfully applied to penguins (Cherel 2008; Strickland et al. 2008; Tierney et al. 2008; Juáres et al. 2016). SIA is based on the evidence that isotopic values of consumers (Hobson and Clark 1993) are directly related to the assimilated diet, since tissues are synthetized from the nutrients formerly assimilated, reflecting their isotopic composition in a predictable manner (DeNiro and Epstein 1978; Hobson and Clark 1992a, b; Bearhop et al. 2004; Newsome et al. 2007; Calizza et al. 2018; Rossi et al., 2019; Sporta Caputi et al., 2020) Since different tissues have different isotopic turnover rates and are produced at different times of the year (Hobson and Clark 1992a; Cherel et al. 2005a; Juáres et al. 2016), diet can be inferred at the different times according to the tissues or biological matrices analysed (Hobson and Clark 1993).

The aim of this study is to reconstruct and compare the year-round diet of the Adélie and Emperor Penguin from different Ross Sea colonies. To achieve this goal, the Carbon and Nitrogen stable isotopes of different biological matrices (feathers, eggshell membranes, and guano) were analysed, providing information related to different phases of the life cycle of these predators (Hobson and Clark 1992a; Cherel et al. 2005a; Juáres et al. 2016). Shell membrane provides information on diet before the breeding period (Astheimer and Grau 1985; Emslie and Patterson 2007; Strickland et al. 2008; Polito et al. 2009; Juáres et al. 2016) that corresponds to spring for Adélie Penguins. Instead, female Emperor Penguins fast throughout oogenesis (Speake et al. 1999; Connan et al., 2019) and egg components are produced using stored reserves. For this reason, the shell membrane in this species provides information on the pre-reproductive fattening period at sea, which corresponds to the winter months of April and May (Kirkwood and Robertson 1997; Speake et al. 1999; Burns and Kooyman 2001). Feathers, which are metabolically inert after synthesis, reflect the resources incorporated during the discrete time interval in which that tissue was grown, in fact they encapsulate information about a bird's diet and foraging habitat related to the pre-moult period (Hobson 1999; Cherel et al. 2000). Specifically, stable isotopes in feathers provide information on the summer and winter diet for Emperor and Adélie Penguins, respectively. The guano provides information on the short-term diet, indicating what the animal has consumed in the days preceding the sampling (Bird et al. 2008). This biological material was collected and used to obtain information about the spring and the summer diets for Emperor and Adélie Penguins, respectively.

Few studies on the foraging ecology of penguins during different stages of their annual cycle were conducted using the stable isotope analysis (Polito et al. 2009, 2011b; Hinke et al. 2015; Juáres et al. 2016). Therefore, by sampling these different biological matrices, we aimed at describing the diet of these two species in different colonies in the Ross Sea and thus acquiring new important information during three phases of their life cycle corresponding to different periods of the year. In agreement with previous studies that highlighted a strong trophic plasticity of the Adélie Penguins (Strickland et al., 2008; Olmastroni et al. 2020; Watanabe et al. 2020) we expected season and site-specific variations of their diet due to variations of krill and P. antarctica abundances following the space-time dynamics of sea ice (Ainley et al.1998, 2003; Ainley 2002; Strickland et al., 2008; Olmastroni et al. 2020). Unlike the Adélie Penguin, which feeds in shallow waters (Cherel and Kooyman 1998; Rodary et al. 2000b; Wienecke et al. 2000), the Emperor Penguin can forage in the whole water column (Cherel and Kooyman 1998; Rodary et al. 2000a; Zimmer et al. 2008), where it can capture a great quantity of deep pelagic fish such as $P$. antarctica (Cherel 2008; Daneri et al. 2018). Thus, according to literature, we expected Emperor Penguin to maintain a mainly piscivorous diet without significant seasonal dietary shifts (Cherel and Kooyman 1998; Barbraud and Weimerskirch 2001; Cherel 2008).

We also hypothesized seasonal interspecific dietary differences due to the different life cycle patterns of Emperor and Adelie penguins.

Determining the resource use of these two penguin species is critical to better understanding the responses of these krill- and fish-dependent predators to possible resource variations associated with climate change and fisheries (Cherel and Hobson 2007; Juáres et al. 2016) and will help establish effective conservation measures for these two species. 


\section{Materials and methods}

\section{Study area and sampling procedures}

The study was carried out at five sites in the coastal area of the Ross Sea, Antarctica: Inexpressible island (163 $43^{\circ} 02^{\prime \prime}$ E, 74 54'01" S), Adélie Cove $\left(164^{\circ} 00^{\prime} 35^{\prime \prime}\right.$ E, $\left.74^{\circ} 45^{\prime} 51^{\prime \prime} \mathrm{S}\right)$, Edmonson Point $\left(165^{\circ} 05^{\prime} 44^{\prime \prime}\right.$ E, $74^{\circ} 19^{\prime} 32^{\prime \prime}$ S), and Cape Hallett $\left(170^{\circ} 13^{\prime} 31^{\prime \prime}\right.$ E, $72^{\circ} 19^{\prime} 13^{\prime \prime}$ S) for Adélie Penguins (Pygoscelis adeliae) and Cape Washington $\left(164^{\circ} 58^{\prime} 02^{\prime \prime} \mathrm{E}\right.$, $74^{\circ} 37^{\prime} 07^{\prime \prime} \mathrm{S}$ ) for Emperor Penguins (Aptenodytes forsteri) (Fig. 1).

Inexpressible Island is in Terra Nova Bay and is bordered to the West by the Nansen Ice Sheet and to the East by Hells Gate and Evans Cove. This area is home to around 24.500 nesting pairs of Adélie Penguins (Harris et al. 2015). Adélie Cove is located on the coast of the Northern foothills of Terra Nova Bay and hosts a colony of Adélie Penguins with approximately 11.200 reproductive pairs (Harris et al. 2015). Edmonson Point, situated in Wood Bay, at the foot of the Eastern slopes of Mount Melbourne, hosts an Adélie Penguin colony of about 1.900 breeding pairs (Harris et al. 2015). Cape Hallett, located at the northern end of the Hallett Peninsula in northern Victoria Land, hosts on average 42,600 breeding pairs of Adélie Penguins (Harris et al. 2015). Cape Washington, in the Northern part of Terra Nova Bay, on the slopes of Mount Melbourne, houses an important colony of Emperor Penguins, with a population of 13,000-25,000 breeding pairs (Harris et al. 2015). The selected colonies lie in a sector of the Ross Sea characterised by marked spatiotemporal variations in sea ice coverage. The strong katabatic wind characterizing the southern portion of the study area and the block of the ice floe by Drygalski Ice Tongue favour the formation a polynya in the area of Inexpressible Island, with an average surface of $1300 \mathrm{~km}^{2}$ (Bromwich and Kurtz 1984; Van Woert 1999). As a consequence, sea ice generally breaks up first at Inexpressible Island. Then, due to dominant winds and sea currents, seasonal sea ice break-up proceeds northward in the direction of Cape Hallett (Petrelli et al. 2008), where sea ice generally persists longer during the summer season.

Samples of eggs, white feathers, and guano were opportunistically collected from each colony during the austral spring 2016-summer 2017 to take into account the two penguins' seasonal diet variation (Fig. 2). At each colony, guano samples were collected in $15 \mathrm{ml}-$ Falcon tubes using a spatula. Feathers and abandoned unhatched eggs were collected near the nests by hand and placed in sterile plastic bags. In the colony of Inexpressible Island no unhatched eggs were found. In order to avoid pseudoreplication of samples, samples of guano, eggs and feathers were collected approximately at a minimum of $50 \mathrm{~m}$ from each other and each

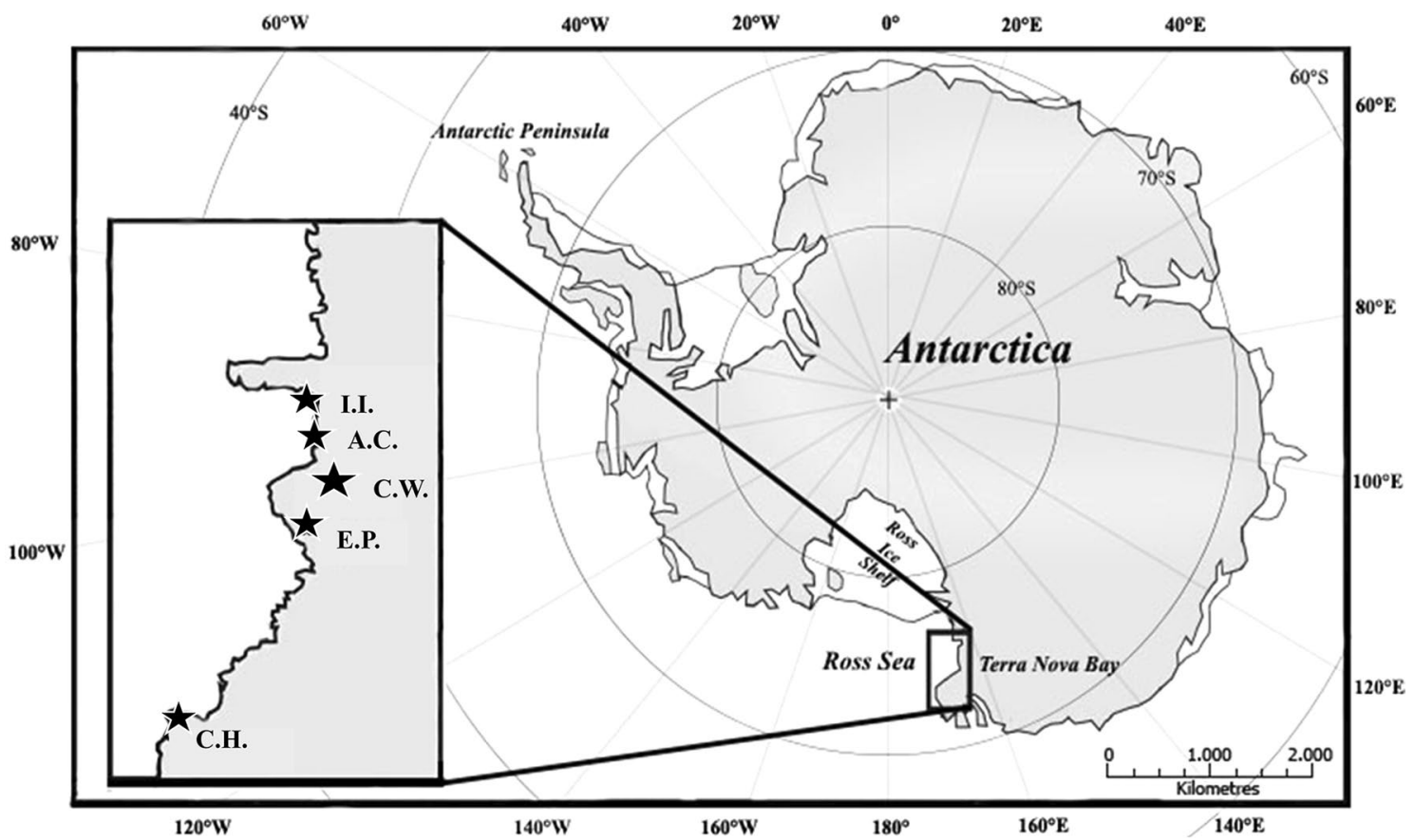

Fig. 1 Sampling area in the Ross Sea (Antarctica). In the small box, the place names indicate the location of the four Adélie Penguin (Pygoscelis adeliae) colonies, Inexpressible Island (I.I.), Adélie Cove (A.C.), Edmonson Point (E.P.), and Cape Hallett (C.H.), and the Emperor Penguin (Aptenodytes forsteri) colony, Cape Washington (C.W.). Information on latitude from Cavalieri and Parkinson (2008) and Harris et al (2015) 
Fig. 2 Principal life cycle phases of Adélie (Pygoscelis adeliae) and Emperor (Aptenodytes forsteri) Penguins and corresponding biological samples collected for $\mathrm{C}$ and $\mathrm{N}$ stable isotope analysis

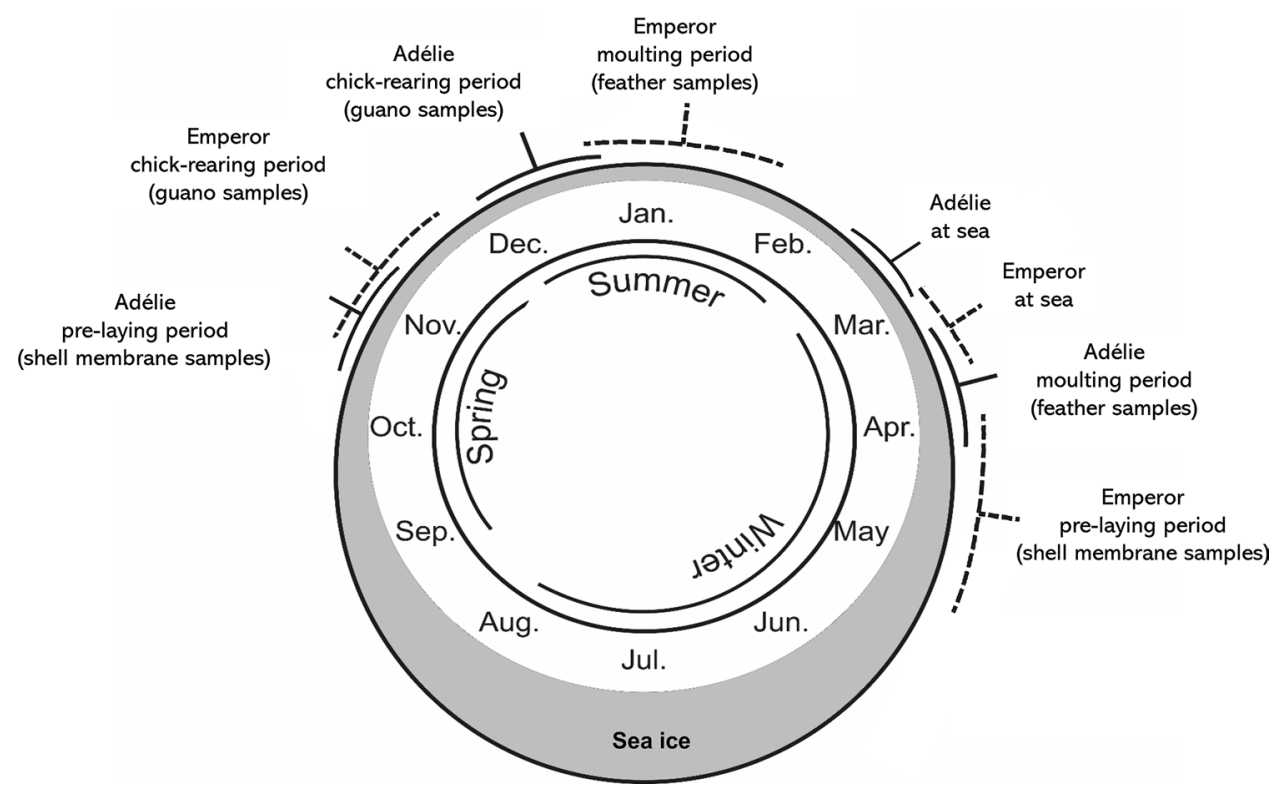

sample was classified as an independent observation (each sample was assigned to a different individual). To obtain isotopic values of penguins' prey, spontaneous vomits of Emperor and Adélie Penguins containing undigested krill and whole fish were opportunistically collected on sea ice and on the ground in spring and summer. Since an oceanographic cruise was not possible, this non-invasive sampling approach made it possible to collect the preys belonging to the specific krill swarms and fish schools actually preyed by penguins in the study area. Specifically, samples of krill were found in all colonies while samples of fish were found only at Edmonson Point and Inexpressible Island. All samples were stored in a refrigerated box until the transport to the Italian scientific station Mario Zucchelli (MZS) in Antarctica. All samples were then enumerated and stored at $-20{ }^{\circ} \mathrm{C}$ until they were transferred and processed in Italy.

\section{Laboratory procedures and stable isotope analysis}

The shell membranes were separated from the eggshells using a surgical blade, dipped in distilled water and cleaned of surface debris, dried and finally cut into small pieces in accordance with Quillfeldt et al. (2009). Guano samples were cleaned, the residues of uric acid rich in inorganic nitrogen were removed with a scalpel in order to reduce any alteration during the nitrogen isotope analysis (Bird et al. 2008). In order to remove surface oils and impurities, feathers were washed with a sonic bath in a $2: 1$ chloroform-methanol, rinsed with distilled water, dried at $60{ }^{\circ} \mathrm{C}$ in oven for at least $24 \mathrm{~h}$ and then cut into small fragments (Graves et al. 2018).

Samples of penguin prey were identified at the lowest possible taxonomic level: fish at the species level ( $P$. antarctica) and krill at the genus level (Euphausia). A sample of dorsal muscle was taken from each individual of Pleuragramma antarctica (Darnaude et al. 2004; Wolters et al. 2018). Krill was not acidified to remove carbonates as each sample was stripped of the exoskeleton to collect only krill muscle. Samples of eggshell membrane, guano and penguin prey were pulverized using a ball mill (Mini-Mill Frits Pulverisette 23: Fritsh Instruments, Idar-Oberstein, Germany). All samples were then weighed and pressed in tin capsules for the Stable Isotopes Analysis. Specifically, aliquots of 1.0-1.5 mg were used for the analyses. Each sample was analyzed in two replicates using an Elementar Vario Micro-Cube elemental analyzer (Elementar Analysen Systeme GmbH, Germany) coupled with an IsoPrime100 continuous flow mass spectrometer (Isoprime Ltd., Cheadle Hulme, UK), and the mean values were used in subsequent analyses. Carbon $(C)$ and Nitrogen $(\mathrm{N})$ isotopic values were expressed in $\delta$ units $\left(\delta^{13} \mathrm{C}\right.$; $\left.\delta^{15} \mathrm{~N}\right)$ as parts per-thousand (\%o) deviations from international standards: Vienna Pee Dee Belemnite (PDB) for C and atmospheric $\mathrm{N}_{2}$ for $\mathrm{N}$. Isotopic ratios were computed according to the equation:

$\delta X(\%)=\left[\left(\frac{\text { Rsample }}{\text { Rstandard }}\right)-1\right] \times 1000$

where $X$ is the $C$ or $N$ isotope and $R$ is the heavy-to-light isotope ratio of the respective element $\left({ }^{13} \mathrm{C} /{ }^{12} \mathrm{C} ;{ }^{15} \mathrm{~N} /{ }^{14} \mathrm{~N}\right.$; Coplen 2011). Results were calibrated to International Atomic Energy Agency reference materials (IAEA-CH-3, IAEA-CH3 and USGS24 for $\delta^{13} \mathrm{C}$; IAEA-N1, IAEA-N2 and USGS25 for $\left.\delta^{15} \mathrm{~N}\right)$. Caffeine IAEA-600 $\left(\mathrm{C}_{8} \mathrm{H}_{10} \mathrm{~N}_{4} \mathrm{O}_{2}\right)$ was used as the internal laboratory standard $\left(\delta^{15} \mathrm{~N}=1.00 \%\right.$ 。 and $\% \circ \delta^{13} \mathrm{C}=-27.77 \%$ ). Measurement errors associated 
with the linearity and stability of the mass spectrometer were typically smaller than $0.05 \%$, while the standard deviation of repeated measurements of lab standard material (one replicate every 10 analyses) was typically $\pm 0.02 \%$ for $\delta^{13} \mathrm{C}$ and $\pm 0.07 \%$ for $\delta^{15} \mathrm{~N}$. Finally, $\delta^{13} \mathrm{C}$ values of fish and krill with $\mathrm{C}: \mathrm{N}$ ratio $>3.32 \%$ were corrected for lipid content in accordance with Post et al. (2007) and the corrected values are reported in the text, tables and figures. No lipid correction was applied for guano, feathers and shell membrane samples.

\section{Data analysis}

Data analysis was conducted with the Statistical Package for the Social Science (SPSS) software. The R package SIMMR (Stable Isotope Mixing Models in R, Parnell and Inger 2019) was used to estimate the relative contribution of prey (i.e., fish and krill) to the penguins' diet.

The Analysis of Variance (ANOVA) was performed to compare $\delta^{13} \mathrm{C}$ and $\delta^{15} \mathrm{~N}$ values among Adélie Penguin colonies within the same season (by comparing the same biological matrix), as well as to compare isotopic values of the same colony among seasons.

The $t$-test was used for comparisons between krill and fish isotopic values and between the Emperor Penguin and Adélie Penguin of the Edmonson Point colony (the closest Adélie Penguin colony to Cape Washington) in winter and summer.

To compare different tissues, which are characterized by different Trophic Enrichment Factor (i.e., TEF, the isotopic differences between the consumer's tissue and its food sources due to metabolism; McCutchan et al. 2003), the TEF values reported in literature were subtracted from the isotopic values of samples. Since in the literature there are not specific TEFs for the feathers and the shell membranes of Adélie and Emperor Penguin, we have used published TEFs of penguin species belonging to the same genera of the two species. Different TEF values were used for the feathers of Emperor Penguin $\left(\Delta^{13} \mathrm{C}=0.7 \pm 0.8 \% ; \Delta^{15} \mathrm{~N}=3.1 \pm 0.8 \%\right.$ o of Aptenodytes patagonicus; Cherel et al. 2005b) and Adélie Penguin $\left(\Delta^{13} \mathrm{C}=1.3 \pm 0.5 \%\right.$; $\Delta^{15} \mathrm{~N}=3.5 \pm 0.4 \%$ of Pygoscelis papua; Polito et al. 2011a for), while the same TEF values of eggshell membrane were used for both species $\left(\Delta^{13} \mathrm{C}=2.8 \pm 0.5 \% ; \Delta^{15} \mathrm{~N}=4.4 \pm 0.5 \%\right.$; Polito et al. 2009 for Pygoscelis papua), as they were the only values reported in the literature. The fractionation of guano was considered equal to 0 for both isotopes (Bird et al. 2008). Indeed, the guano, and in particular the solid component, consists largely of organic material not metabolized by the organism, therefore the phenomenon of fractionation for this type of biological matrix is reduced or absent (Mizutani et al. 1992; Bird et al. 2008). These values have been already used in several studies (Davies et al. 2009; Raya Rey et al. 2012;
Juáres et al. 2016). Nevertheless, we acknowledge that variations in the TEF values potentially affect mixing model outputs (Parnell et al., 2010). Thus, we performed a sensitivity analysis of the outputs to variations in TEFs in accordance with Costantini et al. (2018). Due to the scarcity of information on specific TEF values referring to the two penguin or congeneric species, the TEF of each tissue was independently increased or decreased by $15 \%$ and $30 \%$ for $\delta^{15} \mathrm{~N}$ and $\delta^{13} \mathrm{C}$ values, resulting in nine different TEF combinations to be used in mixing models (Online Resource 1). The results obtained with different TEFs were compared using ANOVA for repeated measures and the associated Tukey's post hoc comparison.

In order to quantify the contribution of the different prey in the diet of both penguin species in summer, spring and winter, we used the SIMMR Bayesian stable isotope mixing model in R environment (Parnell and Inger 2019). This model requires the isotopic values of consumers and potential resources (mean and standard deviation), and an appropriate Trophic Enrichment Factor (TEF), as inappropriate TEF values will lead to inaccurate interpretations (Bond and Diamond 2011). We performed a mixing model using two resources, krill and fish, calculated by using the mean $\delta^{13} \mathrm{C}$ and $\delta^{15} \mathrm{~N}$ values of Euphausia and Pleuragramma antarctica samples, respectively (see "Result" section). The output of the model is a density function distribution of plausible proportion values, whose central tendency (mode, mean, median) and upper and lower limits of credibility intervals (CI: $50 \%, 75 \%, 95 \%$ ) reveal the range of contributions of each resource to penguins' diet (Parnell et al. 2010).

To investigate the seasonal differences in diet in each colony and between Emperor Penguins and Adélie Penguins, the consumption of krill was compared across groups using the function 'compare groups' from the SIMMR package (Parnell and Inger 2019). This function gives the probability, based on Bayesian information criterion $\left(\mathrm{P}_{\mathrm{BIC}}\right)$, that the proportion of any diet source in one treatment is greater than in another treatment, where $\mathrm{P}_{\mathrm{BIC}}>0.95$ indicates a significant difference (Masson 2011; da Silva Santana et al. 2020).

\section{Results}

Mean $\delta^{13} \mathrm{C}$ and $\delta^{15} \mathrm{~N}$ values differed significantly among fish and krill (Figs. 3 and $4 ; t$-test, $t_{\delta 13 \mathrm{C}}=-4.41$ and $t_{\delta 15 \mathrm{~N}}=-10.16, p$ always $\left.<0.0001\right)$.

$\delta^{13} \mathrm{C}$ and $\delta^{15} \mathrm{~N}$ values of Emperor Penguin's guano were depleted compared to feathers and shell membranes (Table 1). Comparisons of $\delta^{13} \mathrm{C}$ and $\delta^{15} \mathrm{~N}$ values corrected by TEF indicated significant differences between the three biological matrices, and thus between seasons (Table 2, Figs. 2 and 3). In accordance, the consumption proportions of krill and fish were found to vary seasonally. Specifically, 


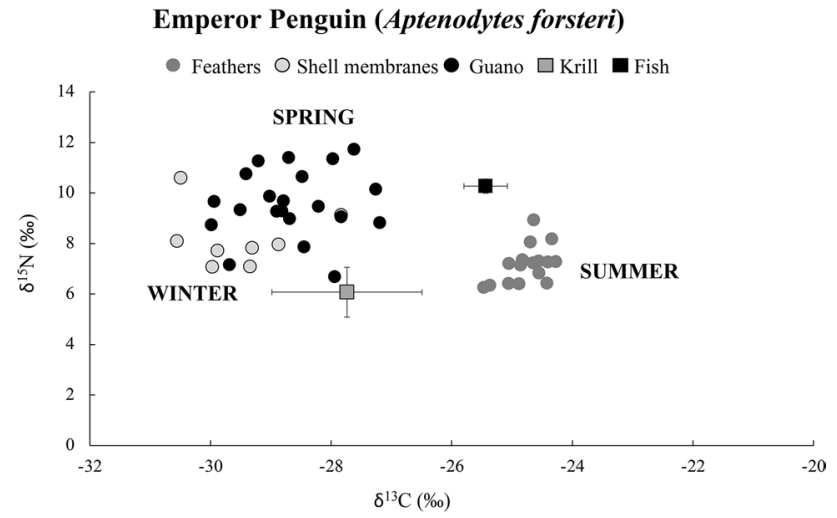

Fig. 3 Isotopic biplot of Emperor Penguin (Aptenodytes forsteri) in winter (shell membranes), spring (guano) and summer (feathers) and their principal prey (fish and krill; mean \pm standard deviation). The $\delta^{13} \mathrm{C}$ and $\delta^{15} \mathrm{~N}$ values of tissues and guano were corrected for the respective TEFs krill contribution to Emperor Penguin's diet was remarkably greater in summer than in spring $\left(70 \%\right.$ vs $29 \% ; P_{\mathrm{BIC}}=0.79$; Table 3), indicating krill-based diet and fish-based diet in the two seasons, respectively. Krill and fish contributions were more similar in winter, although krill was still the preferred prey (Table 3 ).

In the three southernmost colonies, feathers of Adélie Penguins had enriched $\delta^{13} \mathrm{C}$ and $\delta^{15} \mathrm{~N}$ values compared to eggshell membranes, while in Cape Hallett, these tissues had similar isotopic values (Table 1). The $\delta^{13} \mathrm{C}$ and $\delta^{15} \mathrm{~N}$ values of feathers, eggshell membranes and guano corrected by the respective TEF differed significantly in every colony, except Cape Hallett for the $\delta^{15} \mathrm{~N}$ values, thus indicating diet differences among seasons (Table 2). Except for the eggshell membranes, which indicate spring feeding, they differed also among colonies (Table 3). Guano in summer always had intermediate isotopic values (Fig. 4). In accordance with the different isotopic values of the three biological matrices, the Adélie Penguin's diet varied seasonally in all the colonies. Specifically, krill consumption was highest in spring and lowest in winter, although in Cape Hallett it was notably

\section{Adélie Penguin (Pygoscelis adeliae) \\ Feathers $\bigcirc$ Shell membranes $\bullet$ Guano $\square$ Krill $\square$ Fish}

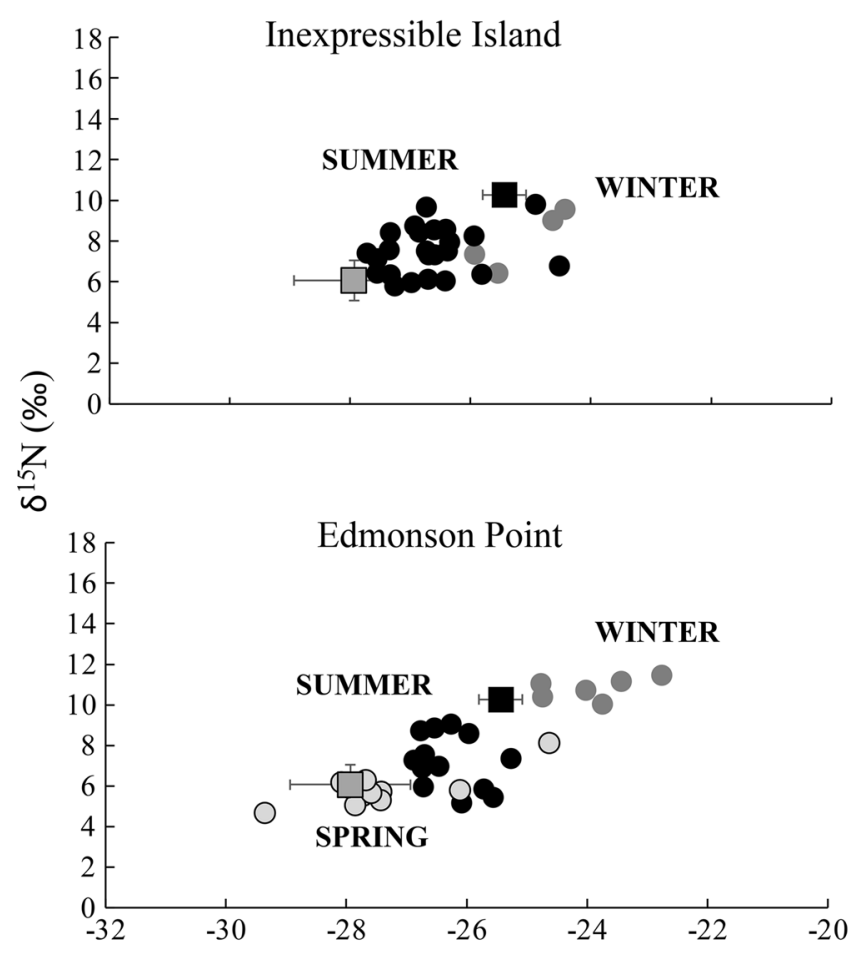

$\delta^{13} \mathrm{C}(\%)$
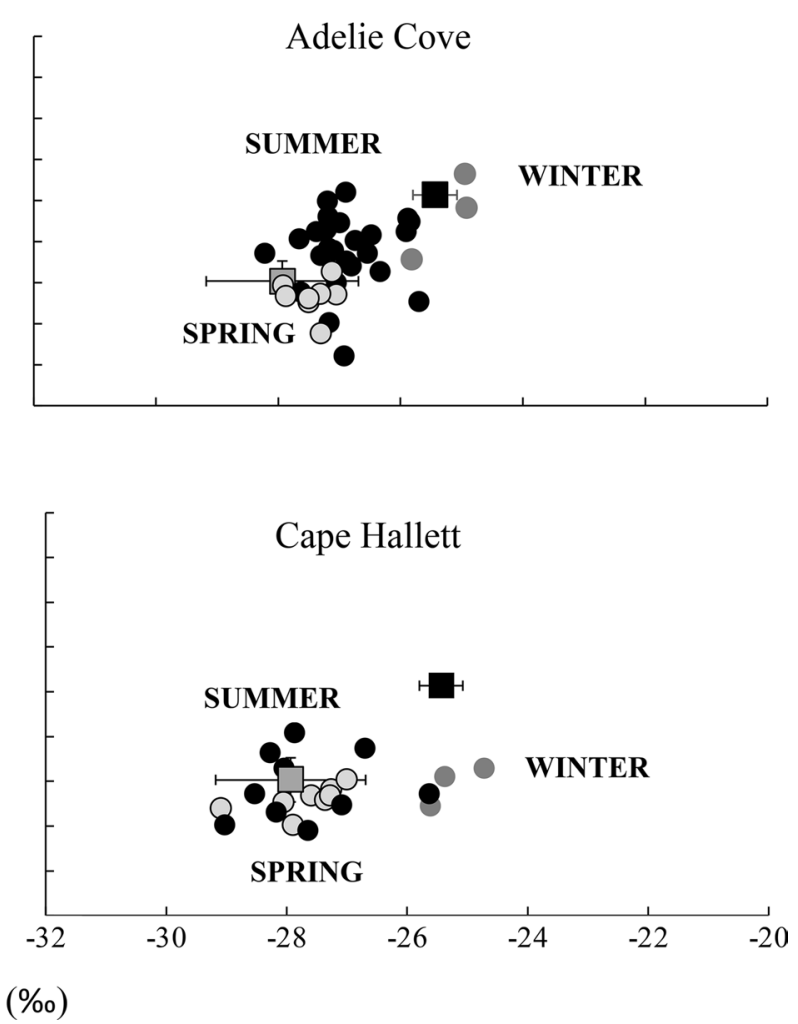

four colonies. The $\delta^{13} \mathrm{C}$ and $\delta^{15} \mathrm{~N}$ values of tissues and guano were corrected for the respective TEFs
Fig. 4 Isotopic biplot of Adélie Penguin (Pygoscelis adeliae) in winter (shell membranes), summer (guano) and spring (feathers) and their principal prey (fish and krill; mean \pm standard deviation) in the 
Table $1 \delta^{13} \mathrm{C}$ and $\delta^{15} \mathrm{~N}(\%)$, percentage of Carbon and Nitrogen and sample size

\begin{tabular}{|c|c|c|c|c|c|c|c|}
\hline Site & Tissue & Period & $\begin{array}{l}\delta^{13} \mathrm{C}(\% \circ) \\
\text { Mean } \pm \text { SD }\end{array}$ & $\begin{array}{l}\delta^{15} \mathrm{~N}(\% o) \\
\text { Mean } \pm \text { SD }\end{array}$ & $\begin{array}{l}\% \mathrm{C} \\
\text { Mean } \pm \mathrm{SD}\end{array}$ & $\begin{array}{l}\% \mathrm{~N} \\
\text { Mean } \pm \mathrm{SD}\end{array}$ & $n^{\circ}$ \\
\hline \multicolumn{8}{|l|}{ Emperor Penguin } \\
\hline \multirow[t]{3}{*}{ Cape Washington } & Feathers & Summer & $-24.06 \pm 0.34$ & $10.27 \pm 0.72$ & $48.52 \pm 0.92$ & $15.69 \pm 0.36$ & 17 \\
\hline & Membranes & Winter & $-26.73 \pm 0.90$ & $12.58 \pm 1.17$ & $47.50 \pm 514$ & $11.92 \pm 1.93$ & 8 \\
\hline & Guano & Spring & $-28.65 \pm 0.82$ & $9.58 \pm 1.35$ & $39.36 \pm 7.02$ & $14.79 \pm 1.88$ & 21 \\
\hline \multicolumn{8}{|l|}{ Adélie Penguin } \\
\hline \multirow[t]{2}{*}{ Inexpressible Island } & Feathers & Winter & $-23.41 \pm 1.14$ & $12.01 \pm 1.58$ & $48.63 \pm 0.86$ & $15.81 \pm 0.26$ & 5 \\
\hline & Guano & Summer & $-26.70 \pm 0.75$ & $6.94 \pm 1.76$ & $42.33 \pm 6.50$ & $8.99 \pm 2.56$ & 28 \\
\hline \multirow[t]{3}{*}{ Adélie Cove } & Feathers & Winter & $-23.93 \pm 0.51$ & $12.84 \pm 2.10$ & $46.05 \pm 0.20$ & $14.82 \pm 0.20$ & 3 \\
\hline & Membranes & Spring & $-27.48 \pm 0.32$ & $5.33 \pm 0.85$ & $44.37 \pm 1.94$ & $14.04 \pm 2.24$ & 8 \\
\hline & Guano & Summer & $-26.91 \pm 0.60$ & $7.54 \pm 1.80$ & $41.72 \pm 5.67$ & $8.72 \pm 2.02$ & 26 \\
\hline \multirow[t]{3}{*}{ Edmonson Point } & Feathers & Winter & $-22.12 \pm 0.53$ & $11.23 \pm 1.01$ & $47.72 \pm 0.95$ & $15.51 \pm 0.39$ & 7 \\
\hline & Membranes & Spring & $-27.47 \pm 1.14$ & $5.89 \pm 0.85$ & $47.07 \pm 2.64$ & $13.18 \pm 0.60$ & 12 \\
\hline & Guano & Summer & $-26.44 \pm 0.78$ & $6.48 \pm 1.48$ & $37.50 \pm 6.24$ & $8.42 \pm 2.30$ & 15 \\
\hline \multirow[t]{5}{*}{ Cape Hallett } & Feathers & Winter & $-24.38 \pm 0.44$ & $5.87 \pm 0.75$ & $48.54 \pm 1.70$ & $15.56 \pm 0.10$ & 4 \\
\hline & Membranes & Spring & $-27.72 \pm 0.66$ & $5.24 \pm 0.60$ & $45.01 \pm 0.84$ & $12.84 \pm 0.84$ & 8 \\
\hline & Guano & Summer & $-28.45 \pm 1.03$ & $4.59 \pm 1.97$ & $38.45 \pm 3.98$ & $9.04 \pm 2.62$ & 11 \\
\hline & Krill & & $-27.74 \pm 1.24$ & $6.07 \pm 0.99$ & $46.14 \pm 6.68$ & $10.03 \pm 2.06$ & 19 \\
\hline & Fish & & $-25.44 \pm 0.36$ & $10.27 \pm 0.28$ & $43.98 \pm 2.30$ & $13.15 \pm 0.80$ & 10 \\
\hline
\end{tabular}

$\left(\mathrm{n}^{\circ}\right)$ of feathers, eggshell membranes and guano of Emperor (Aptenodytes forsteri) and Adélie (Pygoscelis adeliae) Penguins at different sites in the Ross Sea (prior to correction by TEFs) and penguin main resources (krill and fish). The period in which each tissue or guano provides information on the diet is specified. Shell membranes in Inexpressible Island are not available

Table 2 Comparison (one way ANOVA) of $\delta^{13} \mathrm{C}$ and $\delta^{15} \mathrm{~N}$ values, corrected for relative TEFs, among seasons at each penguin colony

\begin{tabular}{|c|c|c|c|c|c|c|c|}
\hline \multirow[t]{2}{*}{ Species } & \multirow[t]{2}{*}{ Colony } & \multirow[t]{2}{*}{ Variable } & \multirow[t]{2}{*}{ df } & \multicolumn{2}{|c|}{$\delta^{13} \mathrm{C}(\% o)$} & \multicolumn{2}{|c|}{$\delta^{15} \mathrm{~N}(\% o)$} \\
\hline & & & & $\mathrm{F}$ & $\mathrm{p}$ & $\mathrm{F}$ & $\mathrm{p}$ \\
\hline \multicolumn{8}{|c|}{ (Aptenodytes forsteri) } \\
\hline \multirow{4}{*}{$\begin{array}{l}\text { Adélie Penguin } \\
\text { (Pygoscelis } \\
\text { adeliae) }\end{array}$} & Inexpressible Island & Season & $1 *$ & 25.61 & $<0.0001$ & 3.44 & 0.07 \\
\hline & Adélie Cove & Season & 2 & 17.83 & $<0.0001$ & 8.22 & 0.001 \\
\hline & Edmonson Point & Season & 2 & 8.89 & $<0.0001$ & 54.35 & $<0.0001$ \\
\hline & Cape Hallett & Season & 2 & 17.81 & $<0.0001$ & 0.90 & 0.42 \\
\hline
\end{tabular}

*Eggshell membranes in Inexpressible Island not available high in all the seasons and the seasonal differences observed were very small (Inexpressible Island, $P_{\mathrm{BIC}}=0.93$; Adélie Cove $P_{\mathrm{BIC}}=0.98$; Edmonson Point, $P_{\mathrm{BIC}}=0.99$, Cape Hallett, $P_{\mathrm{BIC}}=0.43$; Table 3 ). The consumption of prey did not change significantly with different combinations of TEFs of feathers and eggshell (ANOVA for repeated measures and Tukey's post hoc comparison, feathers: $F_{8,36}=1.30, p=0.28$; eggshell: $F_{8,27}=1.36, p=0.26$; for sensitivity analysis, Online Resources 2 and 3).

From comparisons of diets between Emperor and Adélie Penguins in the two neighboring colonies (i.e., Cape Washington and Edmonson Point, respectively), no significant differences were found for either $\delta^{13} \mathrm{C}$ or $\delta^{15} \mathrm{~N}$ values of feathers and guano, corrected by their TEFs, which indicated, respectively, the summer diet of the two species ( $t$ test: $t=-0.95, p=0.35$ and $t=0.11, p=0.92$, respectively). These values were associated with similar high percentages of krill consumption $\left(P_{\mathrm{BIC}}=0.53\right.$; Table 3$)$. By contrast, the two species significantly differed in both $\delta^{13} \mathrm{C}$ and $\delta^{15} \mathrm{~N}$ values of eggshell membranes and feathers, corrected by TEF, which indicated the winter diet of the two species, respectively ( $t=-13.09$ and $t=5.18, p<0.0001$ respectively). These values revealed significantly higher percentages of krill consumption by Emperor Penguin than Adéelie Penguin 
Table 3 Diet composition (\% contribution of fish and krill) of Emperor (Aptenodytes forsteri) and Adélie (Pygoscelis adeliae) Penguins in the different seasons of the year 2016-2017 and in different colonies in the Ross Sea

\begin{tabular}{|c|c|c|c|c|c|c|}
\hline Colony & $\begin{array}{l}\text { Winter } \\
\text { Krill }\end{array}$ & Fish & $\begin{array}{l}\text { Spring } \\
\text { Krill }\end{array}$ & Fish & $\begin{array}{l}\text { Summer } \\
\text { Krill }\end{array}$ & Fish \\
\hline \multicolumn{7}{|l|}{ Emperor Penguin } \\
\hline Cape Washington & $59 \%(34-89)$ & $41 \%(21-66)$ & $29 \%(12-66)$ & $71 \%(35-88)$ & $70 \%(59-79)$ & $30 \%(21-40)$ \\
\hline \multicolumn{7}{|l|}{ Adélie Penguin } \\
\hline Inexpressible Island & $31 \%(15-67)$ & $69 \%(33-95)$ & NA & NA & $64 \%(53-75)$ & $36 \%(25-47)$ \\
\hline Adélie Cove & $14 \%(2-46)$ & $86 \%(55-98)$ & $88 \%$ (69-99) & $12 \%(2-31)$ & $61 \%(52-70)$ & $39 \%(30-49)$ \\
\hline Edmonson Point & $9 \%(1-26)$ & $91 \%(74-98)$ & $93 \%$ (83-99) & $7 \%(1-17)$ & $70 \%(52-87)$ & $30 \%(13-48)$ \\
\hline Cape Hallett & $72 \%(40-97)$ & $28 \%(13-50)$ & $92 \%(76-99)$ & $8 \%(1-24)$ & $90 \%(76-98)$ & $10 \%(2-24)$ \\
\hline
\end{tabular}

The table shows the percentage in the diet (mean 2.5-97.5\% C.I.) of fish (Pleuragramma antarctica) and krill (genus Euphausia) for each colony. Shell membranes in Inexpressible Island not available (NA)

Table 4 Comparison (one way ANOVA) of $\delta^{13} \mathrm{C}$ and $\delta^{15} \mathrm{~N}$ values among the four Adélie Penguin (Pygoscelis adeliae) colonies in the Ross Sea in summer and winter

\begin{tabular}{|c|c|c|c|c|c|}
\hline \multirow[t]{2}{*}{ Season } & \multirow[t]{2}{*}{$\mathrm{df}$} & \multicolumn{2}{|c|}{$\delta{ }^{13} \mathrm{C}(\% \circ)$} & \multicolumn{2}{|c|}{$\delta^{15} \mathrm{~N}(\% o)$} \\
\hline & & $F$ & $p$ & $F$ & $p$ \\
\hline Summer & 3 & 8.12 & $<0.0001$ & 4.02 & 0.011 \\
\hline Winter & 3 & 7.35 & 0.003 & 20.22 & $<0.0001$ \\
\hline Spring & $2 *$ & 0.28 & 0.75 & 2.08 & 0.15 \\
\hline
\end{tabular}

*Eggshell membranes in Inexpressible Island not available

$\left(P_{\mathrm{BIC}}=1\right.$; Table 4$)$. The percentages of krill consumption differed also in spring as indicated by the significant isotopic difference between the guano of Emperor Penguins and the eggshell membranes of Adélie Penguins ( $t$ test: $t=-3.54$, $p=0.001$ and $t=8.70, p<0.0001)$. However, in this season Adélie Penguin consumed a greater proportion of krill than the other species $\left(P_{\mathrm{BIC}}=0.99\right)$.

\section{Discussion}

Emperor (Aptenodytes forsteri) and Adélie (Pygoscelis adeliae) Penguins, which inhabit the southernmost latitudes on our planet, are extremely adapted to spend their whole life in the harsh Antarctic environment (Cherel 2008). Here, their life cycle is tightly related to the seasonality of sea ice, which represents a key substrate for breeding and seasonal migrations as well as a key foraging habitat (Ainley et al. 1998; Bluhm et al. 2010; Lyver et al. 2011).

In order to access open waters throughout the year, penguins may have to migrate thousands of kilometers along the edge of the sea ice (Ainley 2002; Kooyman et al. 2004; Juáres et al. 2016). This makes the study of these species extremely difficult, especially in winter, when darkness, sea ice extent and low temperatures prevent direct observations and sample collections. As a result, there are only few documents describing the feeding behavior of these two species throughout the year (Cherel 2008; Juáres et al. 2016).

Thanks to SIA of guano, eggshell membranes, feathers and the main prey (i.e., krill and P. antarctica) of Emperor and Adélie Penguins, we reconstructed the intra-annual diet of these two predators in five colonies along the coast of the Ross Sea. Since the Euphausiids occupy a lower trophic position than $P$. antarctica (Quillfeldt et al. 2005; Cherel 2008; Strickland et al. 2008), variations in the consumption of these preys by penguins were reflected in variations in the isotopic values of penguin tissues (Quillfeldt et al. 2005; Cherel 2008; Strickland et al. 2008; Tierney et al. 2008).

Our results clearly indicate spatio-temporal variations in the isotopic values of penguin tissues and guano, reflecting changes in diet across seasons and colonies as well as differences between the two species. The study area was an ideal laboratory for comparing penguin diets under different sea ice conditions as these colonies are located in sites characterized by differences in ice persistence, which in turn influences the abundance of krill and fish, the two main resources of Emperor and Adélie Penguins (Knox 1994; Ainley et al.1998, 2003; 2018; Ainley 2002; Watanuki et al. 2002; Koubbi et al. 2011; Polito et al. 2011b; Meyer et al. 2017). Specifically, a greater availability of krill as prey for penguins occurs in periods or areas characterized by greater persistence and extension of the ice pack, while the fish $P$. antartica is more frequent in open sea areas without ice cover (Ainley et al.1998, 2003; Ainley 2002; Wienecke et al. 2000; Strickland et al. 2008).

Some studies have indicated that the Emperor Penguin's diet is mainly based on fish consumption and this food preference is explained by its foraging pattern (Cherel and Kooyman 1998; Barbraud and Weimerskirch 2001; Cherel 2008). Unlike the smaller Adélie Penguins, which feed in shallower pelagic waters, where krill is concentrated (Cherel 
and Kooyman 1998; Rodary et al. 2000b; Wienecke et al. 2000), the Emperor Penguins make dives that can reach $500 \mathrm{~m}$ depth at which it is possible to prey on fish (Cherel and Kooyman 1998; Rodary et al. 2000a; Cherel 2008; Zimmer et al. 2008). Although our results show that fish is part of the Emperor Penguin's diet throughout the year, the significant differences in isotopic values between seasons and the results of Bayesian mixing models indicate remarkable krill consumption, in particular in summer and winter. During the austral winter, this species performs long migration towards the breeding sites, far from the open sea areas due to the great sea ice extension (Kirkwood and Robertson, 1997; Wienecke and Robertson 1997; Burns and Kooyman 2001). Since female emperor penguins fast during this phase in order to store energy reserves (Speake et al. 1999; Connan et al., 2019), they spend the pre-breeding fattening period foraging the most available prey in the nearest polynya, if present or, alternatively, in the shelf waters (Kirkwood and Robertson 1997; Speake et al. 1999; Burn and Kooyman 2001; Michelot et al, 2020). In agreement with Kirkwood and Robertson (1997) our results showed that the winter diet of this species consists mainly of krill, which feeds on sympagic algae growing under the surface of the ice pack and, thus, is extremely abundant in this season (Ainley et al.1998, 2003; Ainley 2002; Wienecke et al. 2000; Strickland et al. 2008). The enriched $\mathrm{C}$ and $\mathrm{N}$ isotopic values observed in spring indicate that in this season the Emperor Penguin diet was mainly based on fish. For this species, spring represents the chick-rearing period and, since fish is a more energetic resource than krill (Watanuki et al. 2002; Ainley et al. 2003; Tierney et al. 2008), when possible adults feed on this highquality prey for their chicks and for themselves to recover the energy spent on the care of the offspring (Cherel 2008; Tierney et al. 2008). Summer represents the moulting period for the Emperor Penguins and during this phase the individuals tend to feed heavily to rapidly build up body reserves to cope with the fasting of the following migration period (Kooyman et al., 2004; Wienecke et al., 2004). Results of Bayesian mixing models indicate that Emperor Penguins had a krillbased diet at Cape Washington in summer. Although the presence and abundance of Euphasiids is linked to sea ice (Ainley et al.1998, 2003; Ainley 2002; Wienecke et al. 2000; Strickland et al. 2008), phytoplankton blooms, favoured by increased solar radiation in the water following the summer melting of the sea ice, may have increased the krill local abundance (Saenz et al. 2020; Watanabe et al. 2020) and therefore its consumption by penguins.

The prevalent consumption of krill by Adélie Penguins occurred in spring and summer while in winter we observed a shift to a fish-based diet in all colonies except Cape Hallett. Indeed, in the austral winter the Adélie Penguins, migrating from the breeding sites to the moulting areas, move towards the edge of the pack ice (Juáres et al. 2016), where they have access to open sea areas and then to fish. In Cape Hallett, the northernmost area, the greater persistence of sea ice plausibly leaded to a greater availability of krill than in the other areas (Ainley et al. 1998; Strickland et al. 2008; Lyver et al. 2011). Unlike the other Adélie Penguin colonies, in Cape Hallett, there were no significant seasonal variations in $\delta^{15} \mathrm{~N}$ values, as krill is the most consumed resource in this site throughout the year. In spring, depleted isotopic values in the three southernmost Adélie Penguin colonies indicated increased krill consumption. Female Adélie Penguins adopted a pre-breeding period foraging strategy similar to that of Emperor Penguins observed in winter. They reach the breeding sites, which are far from the open sea areas due to the great extension of the pack ice (Kirkwood and Robertson 1997). Since Adélie Penguins never travel farther than $100 \mathrm{~km}$ from the colony and rarely travel more than 30-50 km (Olmastroni et al. 2020), females forage mainly under sea ice as well as in polynya areas when possible (Kirkwood and Robertson, 1997; Michelot et al. 2020; Watanabe et al. 2020), where there is a large availability of krill (Spindler and Dieckmann 1994; Nicol 2006).

The comparison between the neighboring colonies of Emperor Penguins and Adélie Penguins shows that $\delta^{13} \mathrm{C}$ and $\delta^{15} \mathrm{~N}$ values of these two species differed in spring and winter. These seasonal differences can be related to the different life cycle patterns of these two species, which lead them to forage in different geographic areas during the high sea ice coverage seasons (Cherel 2008). In contrast, since the two colonies are only $30 \mathrm{~km}$ apart, an overlap of the summer foraging areas between the two species is plausible. Indeed, during this season no differences were observed in the $\delta^{13} \mathrm{C}$ and $\delta^{15} \mathrm{~N}$ values between the two species whose diet was based mainly on krill (Strickland et al. 2008; Watanabe et al. 2020).

In summary, contrary to our predictions, the results show that not only the Adélie Penguin but also the Emperor Penguin exhibits a variation in diet over the course of the year. This temporal dietary variation is due to the phases of the life cycle of the two species and the seasonal dynamics of the sea ice that influence the availability of their prey. Furthermore, the variable sea ice persistence along the coasts of the Ross Sea, influencing the spatial availability of prey, determines dietary variability between colonies in Adélie penguins.

The comparison of the isotopic values of different biological matrices has proved to be a valuable tool for reconstructing the intra-annual diets of Adélie and Emperor Penguins. The advantage offered by this 'multi tissue approach' compared to classic methods such as stomach contents analysis or direct observations, is the possibility of collecting information on the trophic ecology of seabirds also when these species are inaccessible for observation or sampling due to their migratory activity or extreme environmental conditions 
(Connan et al. 2019). Although powerful, this approach has some limitations. The main one concerns the use of tissuespecific turnover and isotope fractionation values, as the use of incorrect values can lead to an incorrect interpretation of the results (Dalerum and Angerbjörn 2005; Bond and Diamond 2011). The large inter-specific variation (Vanderklift and Ponsard 2003) makes it necessary to use species-specific fractionation values or, when not available in the literature, fractionation values obtained from phylogenetically related species (Dalerum and Angerbjörn 2005). The knowledge of species-specific tissue turnover rates allows definition of the time window in which the tissue reflects the dietary record (Dalerum and Angerbjörn 2005). On the other hand, the use of metabolically inert matrices that integrate dietary information in a discrete period has made it possible to establish with certainty the diet of the two species in different periods of the year, making us confident of the goodness of the results, which were also robust to relevant variations (i.e., up to $30 \%$ ) in the values of TEF used in mixing models.

\section{Concluding Remarks}

In this study, the stable isotope analysis of different tissues made it possible to reconstruct the intra-annual diet of the Adélie Penguin (Pygoscelis adeliae) and Emperor Penguin (Aptenodytes forsteri) in colonies located in the core of the Ross Sea MPA and never studied before through SIA. Feathers, eggshell membranes and guano provided information from different periods (Jafari et al. 2020), filling gaps associated with the trophic behavior of these endemic species of conservation importance in winter and spring.

Knowledge of the trophic ecology of high trophic level predators can provide useful information on changes occurring at lower trophic levels in the food chain as a consequence of environmental changes (Juáres et al. 2016). Here, comparison of $\mathrm{C}$ and $\mathrm{N}$ stable isotopes between and within species allowed us to detect changes in penguin feeding preferences, providing updated dietary and isotopic reference data useful for future comparisons within the Ross Sea MPA, which represents a biodiversity hotspot and the largest marine protected area on our planet (Ballard et al. 2012; Laffoley et al. 2019). Deepening of the knowledge of the trophic ecology of Adélie and Emperor Penguins represents an important step to understand the mechanisms underlying the structural and functional integrity of the Antarctic ecosystem and to predict how these species will respond to changes in resource availability due to the climate change or overexploitation in the Southern Ocean.
Supplementary Information The online version contains supplementary material available at https://doi.org/10.1007/s00300-021-02925-1.

Acknowledgements This work was funded by the Italian National Antarctic Research Program (PNRA), PNRA2015/AZ1.01 to MLC, and PNRA16_00291 to LR. We thank the PNRA for logistic and operational support, and Italian Colleagues for the collaboration in the field. We thank Loïc N. Michel, other two anonymous Reviewers and the Editor for their helpful comments and suggestions, which substantially improved the manuscript.

Author contributions LR, MLC and EC conceived and designed research. GC and EC conducted the sampling activity. VJ and SSC processed the samples. VJ, DM and GC analysed data. VJ, DM and MLC wrote the manuscript. All authors read, reviewed, approved the manuscript.

Funding Open access funding provided by Università degli Studi di Roma La Sapienza within the CRUI-CARE Agreement. This work was funded by the Italian National Antarctic Research Program (PNRA): PNRA2015/AZ1.01 to MLC, and PNRA16_00291 to LR.

\section{Declarations}

Conflict of interest The Authors declare no conflict and/or competing interests.

Ethical approval The present study is part of the PNRA2015/AZ1.01 and PNRA16_00291 projects. No living organisms were involved. The sampling activity was agreed with the PNRA (Italian National Antarctic Research Program), which issued permits to collect samples in the study area on behalf of the Italian Ministry of Foreign Affairs. Permits were issued in compliance with the "Protocol on Environmental Protection to the Antarctic Treaty", Annex II, art.3).

Data availability All the relevant data and information are within the paper.

Open Access This article is licensed under a Creative Commons Attribution 4.0 International License, which permits use, sharing, adaptation, distribution and reproduction in any medium or format, as long as you give appropriate credit to the original author(s) and the source, provide a link to the Creative Commons licence, and indicate if changes were made. The images or other third party material in this article are included in the article's Creative Commons licence, unless indicated otherwise in a credit line to the material. If material is not included in the article's Creative Commons licence and your intended use is not permitted by statutory regulation or exceeds the permitted use, you will need to obtain permission directly from the copyright holder. To view a copy of this licence, visit http://creativecommons.org/licenses/by/4.0/.

\section{References}

Ainley DG (2002) The Adélie penguin: bellwether of climate change. Columbia University Press, New York

Ainley DG, Wilson PR, Barton KJ, Ballard G, Nur N, Karl B (1998) Diet and foraging effort of Adélie penguins in relation to pack-ice conditions in the southern Ross Sea. Polar Biol 20(5):311-319. https://doi.org/10.1007/s003000050308 
Ainley DG, Ballard G, Barton KJ, Karl BJ, Rau GH, Ribic CA, Wilson PR (2003) Spatial and temporal variation of diet within a presumed metapopulation of Adélie penguins. Condor 105:95-106. https://doi.org/10.1093/Condor/105.1.95

Ainley DG, Dugger KM, La Mesa M, Ballard G, Barton KJ, Jennings S, Karl BJ, Lescroel A et al (2018) Post-fledging survival of Adélie penguins at multiple colonies: chicks raised on fish do well. Mar Ecol Prog Ser 601:239-251. https://doi.org/10.3354/ meps 12687

Arrigo KR, van Dijken GL, Ainley DG, Fahnestock MA, Markus T (2002) Ecological impact of a large Antarctic iceberg. Geophys Res Lett 29(7):8-1. https://doi.org/10.1029/2001GL014160

Astheimer LB, Grau CR (1985) Apparent double blastoderms in Adélie penguin eggs. Condor 87(1):150-151. https://doi.org/10.2307/ 1367150

Ballard G, Jongsomjit D, Veloz SD, Ainley DG (2012) Coexistence of mesopredators in an intact polar ocean ecosystem: the basis for defining a Ross Sea marine protected area. Biol Conserv 156:7282. https://doi.org/10.1016/j.biocon.2011.11.017

Barbraud C, Weimerskirch H (2001) Emperor penguins and climate change. Nature 411(6834):183-186. https://doi.org/10.1038/ 35075554

Bearhop S, Adams CE, Waldron S, Fuller RA, MacLeod H (2004) Determining trophic niche width: a novel approach using stable isotope analysis. J Anim Ecol 73(5):1007-1012. https://doi.org/ 10.1111/j.0021-8790.2004.00861.x

Bird MI, Tait E, Wurster CM, Furness RW (2008) Stable carbon and nitrogen isotope analysis of avian uric acid. Rapid Commun Mass Spectrom 22(21):3393-3400. https://doi.org/10.1002/rcm.3739

Bluhm BA, Gradinger RR, Schnack-Schiel SB (2010) Sea ice meio-and macrofauna. Sea ice, 2nd edn. Wiley-Blackwell, Oxford

Bond AL, Diamond AW (2011) Recent Bayesian stable-isotope mixing models are highly sensitive to variation in discrimination factors. Ecol Appl 21:1017-1023. https://doi.org/10.1890/09-2409.1

Bromwich DH, Kurtz DD (1984) Katabatic wind forcing of the Terra Nova Bay polynya. J Geophys Res Oceans 89(C3):3561-3572. https://doi.org/10.1029/JC089iC03p03561

Brooks CM, Crowder LB, Österblom H, Strong AL (2020) Reaching consensus for conserving the global commons: the case of the Ross Sea. Antarctica Conserv Lett 13(1):e12676. https://doi.org/ 10.1111/conl.12676

Burns JM, Kooyman GL (2001) Habitat use by Weddell seals and emperor penguins foraging in the Ross Sea, Antarctica. Am Zool 41(1):90-98. https://doi.org/10.1093/icb/41.1.90

Calizza E, Careddu G, Sporta Caputi S, Rossi L, Costantini ML (2018) Time-and depth-wise trophic niche shifts in Antarctic benthos. PLoS ONE. https://doi.org/10.1371/journal.pone.0194796

Cavalieri DJ, Parkinson CL (2008) Antarctic sea ice variability and trends, 1979-2006. J. Geophys Research: Oceans 113(C7). https:// doi.org/10.1029/2007JC004564

Cherel Y (2008) Isotopic niches of emperor and Adélie penguins in Adélie Land, Antarctica. Mar Biol 154:813-821. https://doi.org/ 10.1007/s00227-008-0974-3

Cherel Y, Hobson KA (2007) Geographical variation in carbon stable isotope signatures of marine predators: a tool to investigate their foraging areas in the Southern Ocean. Mar Ecol Prog Ser 329:281-287. https://doi.org/10.3354/meps329281

Cherel Y, Kooyman GL (1998) Food of emperor penguins (Aptenodytes forsteri) in the western Ross Sea. Antarctica Mar Biol 130(3):335-344. https://doi.org/10.1007/s002270050253

Cherel Y, Hobson KA, Weimerskirch H (2000) Using stable-isotope analysis of feathers to distinguish moulting and breeding origins of seabirds. Oecologia 122(2):155-162. https://doi.org/10.1007/ PL00008843
Cherel Y, Hobson KA, Bailleul F, Groscolas R (2005a) Nutrition, physiology, and stable isotopes: new information from fasting and molting penguins. Ecology 86(11):2881-2888. https://doi. org/10.1890/05-0562

Cherel Y, Hobson KA, Hassani S (2005b) Isotopic discrimination between food and blood and feathers of captive penguins: implications for dietary studies in the wild. Physiol Biochem Zool 78(1):106-115. https://doi.org/10.1086/425202

Connan M, Dilley BJ, Whitehead TO, Davies D, McQuaid CD, Ryan PG (2019) Multidimensional stable isotope analysis illuminates resource partitioning in a sub-Antarctic island bird community. Ecography 42(11):1948-1959. https://doi.org/10.1111/ecog. 04560

Coplen TB (2011) Guidelines and recommended terms for expression of stable-isotope-ratio and gas-ratio measurement results. Rapid Commun Mass Spectrom 25(17):2538-2560

Costantini ML, Carlino P, Calizza E, Careddu G, Cicala D, Sporta Caputi S, Fiorentino F, Rossi L (2018) The role of alien fish (the centrarchid Micropterus salmoides) in lake food webs highlighted by stable isotope analysis. Freshw Biol 63:1130-1142. https://doi. org/10.1111/fwb.13122

da Silva Santana CA, Wieczorek AM, Browne P, Graham CT, Power AM (2020) Importance of suspended particulate organic matter in the diet of Nephrops norvegicus (Linnaeus, 1758). Sci Rep 10(1):1-11. https://doi.org/10.1038/s41598-020-60367-x

Daneri GA, Negri A, Coria NR, Negrete J, Libertelli MM, Corbalán A (2018) Fish prey of Weddell seals, Leptonychotes weddellii, at Hope Bay, Antarctic Peninsula, during the late summer. Polar Biol 41(5):1027-1031. https://doi.org/10.1007/s00300-018-2255-Z

Dalerum F, Angerbjörn A (2005) Resolving temporal variation in vertebrate diets using naturally occurring stable isotopes. Oecologia 144(4):647-658. https://doi.org/10.1007/s00442-005-0118-0

Darnaude AM, Salen-Picard C, Polunin NVC, Harmelin-Vivien ML (2004) Trophodynamic linkage between river runoff and coastal fishery yield elucidated by stable isotope data in the Gulf of Lions (NW Mediterranean). Oecologia 138:325-332. https://doi.org/10. 1007/s00442-003-1457-3

Davies WE, Hipfner JM, Hobson KA, Ydenberg RC (2009) Seabird seasonal trophodynamics: isotopic patterns in a community of Pacific alcids. Mar Ecol Prog Ser 382:211-219. https://doi.org/ 10.3354/meps07997

DeNiro MJ, Epstein S (1978) Influence of diet on the distribution of nitrogen isotopes in animals. Geochim Cosmochim Acta 45:341351. https://doi.org/10.1016/0016-7037(81)90244-1

Emslie SD, Patterson WP (2007) Abrupt recent shift in $813 \mathrm{C}$ and $815 \mathrm{~N}$ values in Adélie penguin eggshell in Antarctica. Proc Natl Acad Sci USA 104(28):11666-11669. https://doi.org/10.1073/pnas. 0608477104

Graves GR, Newsome SD, Fogel ML (2018) Stable hydrogen isotope variability within and among plumage tracts $\left(\delta^{2} \mathrm{H}_{\mathrm{F}}\right)$ of a migratory wood warbler. PLoS ONE. https://doi.org/10.1371/journal. pone. 0193486

Harris CM, Lorenz K, Fishpool LDC, Lascelles B, Cooper J, Coria NR, Croxall JP, Emmerson L et al (2015) Important Bird Areas in Antarctica 2015. BirdLife Int and Env Research \& Assessment

Hinke JT, Polito MJ, Goebel ME, Jarvis S, Reiss CS, Thorrold SR, Trivelpiece WZ, Watters GM (2015) Spatial and isotopic niche partitioning during winter in chinstrap and Adélie penguins from the South Shetland Islands. Ecosphere. https://doi.org/10.1890/ ES14-00287.1

Hobson KA (1999) Tracing origins and migration of wildlife using stable isotopes: a review. Oecologia 120(3):314-326. https://doi. org/10.1007/s004420050865 
Hobson KA, Clark RG (1992a) Assessing avian diets using stable isotopes I: turnover of 13C in tissues. Condor 94(1):181-188. https:// doi.org/10.2307/1368807

Hobson KA, Clark RG (1992b) Assessing avian diets using stable isotopes II: factors influencing diet-tissue fractionation. Condor 94(1):189-197. https://doi.org/10.2307/1368808

Hobson KA, Clark RG (1993) Turnover of $13 \mathrm{C}$ in cellular and plasma fractions of blood: implications for nondestructive sampling in avian dietary studies. Auk 110(3):638-641. https://doi.org/10. 2307/4088430

Jafari V, Jafari M, Rossi L, Calizza E, Costantini ML (2020) Stable isotope application in animal nutrition science. Iran J Appl Anim Sci 10(3):409-419

Juáres MA, Santos M, Mennucci JA, Coria NR, Mariano-Jelicich R (2016) Diet composition and foraging habitats of Adélie and gentoo penguins in three different stages of their annual cycle. Mar Biol 163(5):105. https://doi.org/10.1007/s00227-016-2886-y

Kirkwood R, Robertson G (1997) The foraging ecology of female emperor penguins in winter. Ecol Monogr 67:155-176. https:// doi.org/10.1890/0012-9615(1997)067[0155:TFEOFE]2.0.CO;2

Knox GA (1994) Biology of the southern ocean. Cambridge University Press, Cambridge

Kooyman GL, Siniff DB, Stirling I, Bengtson JL (2004) Moult habitat, pre-and post-moult diet and post-moult travel of Ross Sea emperor penguins. Mar Ecol Prog Ser 267:281-290. https://doi. org/10.3354/meps 267281

Koubbi P, Hosie G, Constable A, Raymond B, Moteki M, Améziane N, Causse R, Fuentes V et al (2011) Estimating the biodiversity of the shelf and oceanic zone of the d'Urville Sea (East Antarctica) for ecoregionalisation using the CEAMARC (Collaborative East Antarctic Marine Census) CAML surveys. Polar Sci 4:115-133

Laffoley D, Baxter JM, Day JC, Wenzel L, Bueno P, Zischka K (2019) Marine protected areas. World seas: an environmental evaluation. Academic Press, Cambridge. https://doi.org/10.1016/B978-0-12805052-1.00027-9

Lyver PB, MacLeod CJ, Ballard G, Karl BJ, Barton KJ, Adams J, Wilson PR (2011) Intra-seasonal variation in foraging behavior among Adélie penguins (Pygoscelis adeliae) breeding at Cape Hallett, Ross Sea. Antarctica Polar Biol 34(1):49-67. https://doi. org/10.1007/s00300-010-0858-0

Masson MEJ (2011) A tutorial on a practical Bayesian alternative to null-hypothesis significance testing. Behav Res Methods 4:679690. https://doi.org/10.3758/s13428-010-0049-5

McCutchan JH Jr, Lewis WM Jr., Kendall C, McGrath CC (2003) Variation in trophic shift for stable isotope ratios of carbon, nitrogen, and sulfur. Oikos 102(2):378-390. https://doi.org/10.1034/j.16000706.2003.12098.x

Meyer B, Freier U, Grimm V, Groeneveld J, Hunt BPV, Kerwath S, King R, Klaas C et al (2017) The winter pack-ice zone provides a sheltered but foodpoor habitat for larval Antarctic krill. Nat Ecol Evol 1(12):1853-1861. https://doi.org/10.1038/ s41559-017-0368-3

Michelot C, Kato A, Raclot T, Shiomi K, Goulet P, Bustamante P, Ropert-Coudert Y (2020) Sea-ice edge is more important than closer open water access for foraging Adélie penguins: evidence from two colonies. Mar Ecol Prog Ser 640:215-230. https://doi. org/10.3354/meps13289

Mizutani H, McFarlane DA, Kabaya Y (1992) Carbon and nitrogen isotopic signatures of bat guanos as record of past environments. J Mass Spectrom Soc Jpn 40(1):67-68. https://doi.org/10.5702/ massspec. 40.67

Newsome SD, Martinez del Rio C, Bearhop S, Phillips DL (2007) A niche for isotopic ecology. Front Ecol Environ 5(8):429-436. https://doi.org/10.1890/060150.1
Nicol S (2006) Krill, currents, and sea ice: Euphausia superba and its changing environment. Bioscience 56(2):111-120. https://doi.org/ 10.1641/0006-3568(2006)056[0111:KCASIE]2.0.CO;2

Olmastroni S, Fattorini N, Pezzo F, Focardi S (2020) Gone fishing: Adélie penguin site-specific foraging tactics and breeding performance. Antarct Sci 32(3):199-209. https://doi.org/10.1017/S0954 102020000085

Parnell AC, Inger R (2019) Stable isotope mixing models in R with SIMMR: a stable isotope mixing model. Version 0.4, 1. https:// CRAN.R-project.org/package $=$ simmr

Parnell AC, Inger R, Bearhop S, Jackson AL (2010). Source partitioning using stable isotopes: coping with too much variation. PloS one, 5(3):e9672. https://doi.org/10.1371/journal.pone.0009672

Petrelli P, Bindoff NL, Bergamasco A (2008) The sea ice dynamics of Terra Nova Bay and Ross Ice Shelf Polynyas during a spring and winter simulation. J Geophys Res Oceans. https://doi.org/10. 1029/2006JC004048

Polito MJ, Fisher S, Tobias CR, Emslie SD (2009) Tissue-specific isotopic discrimination factors in gentoo penguin (Pygoscelis papua) egg components: implications for dietary reconstruction using stable isotopes. J Exp Mar Biol Ecol 372(1-2):106-112. https://doi. org/10.1016/j.jembe.2009.02.014

Polito MJ, Abel S, Tobias CR, Emslie SD (2011a) Dietary isotopic discrimination in gentoo penguin (Pygoscelis papua) feathers. Polar Biol 34(7):1057-1063. https://doi.org/10.1007/ s00300-011-0966-5

Polito MJ, Trivelpiece WZ, Karnovsky NJE, Patterson WP, Emslie SD (2011b) Integrating stomach content and stable isotope analyses to quantify the diets of Pygoscelid Penguins. PLoS ONE. https:// doi.org/10.1371/journal.pone.0026642

Post DM, Layman CA, Arrington DA, Takimoto G, Quattrochi J, Montaña CG (2007) Getting to the fat of the matter: models, methods and assumptions for dealing with lipids in stable isotope analyses. Oecologia 152:179-189. https://doi.org/10.1007/ s00442-006-0630-x

Quillfeldt P, McGill RAR, Furness RW (2005) Diet and foraging areas of Southern Ocean seabirds and theirprey inferred from stable isotopes: review and case study of Wilson's storm-petrel. Mar Ecol Prog Ser 295:295-304. https://doi.org/10.3354/meps295295

Quillfeldt P, McGill RA, Masello JF, Poisbleau M, van Noordwijk H, Demongin L, Furness RW (2009) Differences in the stable isotope signatures of seabird egg membrane and albumen-implications for non-invasive studies. Rapid Commun Mass Spectrom 23(23):3632-3636. https://doi.org/10.1002/rcm.4286

Raya Rey A, Polito M, Archuby D, Coria N (2012) Stable isotopes identify age- and sex-specific dietary partitioning and foraging habitat segregation in southern giant petrels breeding in Antarctica and southern Patagonia. Mar Biol 159:1317-1326. https://doi. org/10.1007/s00227-012-1912-y

Rodary D, Bonneau W, Le Maho Y, Bost CA (2000a) Benthic diving in male emperor penguins Aptenodytes forsteri foraging in winter. Mar Ecol Prog Ser 207:171-181. https://doi.org/10.3354/meps2 07171

Rodary D, Wienecke BC, Bost CA (2000b) Diving behaviour of Adelie penguins (Pygoscelis adeliae) at Dumont D' Urville, Antarctica: nocturnal patterns of diving and rapid adaptations to changes in sea-ice condition. Polar Biol 23(2):113-120. https://doi.org/10. $1007 / \mathrm{s} 003000050016$

Rossi L, Sporta Caputi S, Calizza E, Careddu G, Oliverio M, Schiaparelli S, Costantini ML (2019) Antarctic food web architecture under varying dynamics of sea ice cover. Sci Rep 9(1):1-13. https://doi.org/10.1038/s41598-019-48245-7

Saenz BT, Ainley DG, Daly KL, Ballard G, Conlisk E, Elrod ML, Kim SL (2020) Drivers of concentrated predation in an Antarctic marginal-ice-zone food web. Sci Rep 10(1):1-17. https://doi.org/ 10.1038/s41598-020-63875-y 
Speake BK, Decrock F, Surai PF, Groscolas R (1999) Fatty acid composition of the adipose tissue and yolk lipids of a bird with a marinebased diet, the emperor penguin (Aptenodytes forsteri). Lipids 34(3):283-290. https://doi.org/10.1007/s11745-999-0365-9

Spindler M, Dieckmann G (1994) Ecological significance of the sea ice biota. Antarctic Science. Springer, Berlin, Heidelberg, pp 60-68

Sporta Caputi S, Careddu G, Calizza E, Fiorentino F, Maccapan D, Rossi L, Costantini M (2020) Seasonal food web dynamics in the Antarctic benthos of Tethys Bay (Ross Sea): implications for biodiversity persistence under different seasonal sea-ice coverage. Front Mar Sci 7:1046. https://doi.org/10.3389/fmars.2020.594454

Strickland ME, Polito M, Emslie SD (2008) Spatial and seasonal variation in Adélie penguin diet as inferred from stable isotope analysis of eggshell. J N C Acad Sci 124:65-71

Tierney M, Southwell C, Emmerson LM, Hindell MA (2008) Evaluating and using stable-isotope analysis to infer diet composition and foraging ecology of Adélie penguins Pygoscelis adeliae. Mar Ecol Prog Ser 355:297-307. https://doi.org/10.3354/meps07235

Van Woert ML (1999) Wintertime dynamics of the Terra Nova Bay polynya. J Geophys Res Oceans 104:1153-1169. https://doi.org/ 10.1029/1999JC900003

Vanderklift MA, Ponsard S (2003) Sources of variation in consumerdiet $\mathrm{d} 15 \mathrm{~N}$ enrichment:a meta analysis. Oecologia 136:169-182. https://doi.org/10.1007/s00442-003-1270-z

Watanabe YY, Ito K, Kokubun N, Takahashi A (2020) Foraging behavior links sea ice to breeding success in Antarctic penguins. Sci Adv 6:eaba4828. https://doi.org/10.1126/sciadv.aba4828

Watanuki Y, Kato A, Sato K, Niizuma Y, Bost CA, Le Maho Y, Naito Y (2002) Parental mass change and food provisioning in Adélie penguins rearing chicks in colonies with contrasting sea-ice conditions. Polar Biol 25(9):672-681. https://doi.org/10.1007/ s00300-002-0399-2

Wienecke BC, Robertson G (1997) Foraging space of emperor penguins Aptenodytes forsteri in Antarctic shelf waters in winter. Mar Ecol Prog Ser 159:249-263. https://doi.org/10.3354/meps159249

Wienecke BC, Lawless R, Rodary D, Bost CA, Thomson R, Pauly T, Roberson G, Kerry KR, LeMaho Y (2000) Adélie penguin foraging behaviour and krill abundance along the Wilkes and Adélie land coasts, Antarctica. DEEP-SEA RES PT II 47(12-13):25732587. https://doi.org/10.1016/S0967-0645(00)00036-9

Wienecke B, Kirkwood R, Robertson G (2004) Pre-moult foraging trips and moult locations of emperor penguins at the Mawson Coast. Polar Biol 27(2):83-91. https://doi.org/10.1007/ s00300-003-0574-0

Wolters JW, Verdonschot RCM, Schoelynck J, Brion N, Verdonschot PFM, Meire P (2018) Stable isotopes measurmements confirm consumption of submerged macrophytes by macroinvertebrates and fish taxa. Aquat Ecol 52:269-280. https://doi.org/10.1007/ s10452-018-9662-7

Zimmer I, Wilson RP, Gilbert C, Beaulieu M, Ancel A (2008) Plötz J (2008) Foraging movements of emperor penguins at Pointe Géologie, Antarctica. Polar Biol 31:229-243. https://doi.org/10.1007/ s00300-007-0352-5

Publisher's Note Springer Nature remains neutral with regard to jurisdictional claims in published maps and institutional affiliations. 